\title{
ANALIZA UČINAKA PROMJENA U MEĐUNARODNIM STANDARDIMA FINANCIJSKOGA IZVJEŠTAVANJA NA USPOREDIVOST I DOSLJEDNOST FINANCIJSKIH IZVJEŠTAJA
}

Cilj rada je ukazati na to utječu li kontinuirane promjene u Međunarodnim standardima financijskoga izvještavanja na usporedivost $i$ dosljednost financijskih izvještaja u kratkom i dugom roku. Za postizanje tog cilja identificirani su čimbenici koji utječu na promjene u računovodstvenim standardima kako bi se ukazalo na to zašto do takvih promjena uopće dolazi.Kako bi se došlo do znanstveno utemeljenih zaključaka, kronološkim redoslijedom analizirane su promjene u 15 Međunarodnih računovodstvenih standardal Međunarodnih standarda financijskoga izvještavanja koje su zabilježene u vremenskom periodu od 1975. do 2018. godine. U istraživačkom procesu analizirana je dostupna izvorna literatura sa sadržajem standarda važećih u određenoj točki vremena. Različite edicije standarda istražene su primjenom odgovarajućih znanstvenih metoda; metode analize, sinteze, komparativne metoda, metode indukcije i dedukcije te ostalih relevantnih znanstvenih metoda. U radu je znanstveno utemeljenim metodama pokazano kako promjene u računovodstvenim standardima mogu imati utjecaja na kvalitetu financijskoga izvještavanja u određenim slučajevima jer onemogućavaju primjenu temeljnih računovodstvenih načela usporedivosti i dosljednosti. Znanstveni doprinos rada očituje se u identificiranju i sistematizaciji ključnih promjena

* I. Pavić, dr. sc., docent, Sveučilište u Zagrebu, Ekonomski fakultet Zagreb (e-mail: ipavic@ efzg.hr). Rad je primljen u uredništvo 26.02.2019. godine, a prihvaćen je za objavu 14.05.2019. godine. 
u standardima te analizi njihova učinka na financijsko izvještavanje poduzeća koja primjenjuju MSFI-e.

Ključne riječi: MSFI, promjene, usporedivost, dosljednost, financijski izvještaji, računovodstveni standardi

\section{UVOD}

Jedna od najznačajnijih pojava u drugoj polovici 20. stoljeća koja je na posredan ili neposredan način zahvatila sve zemlje u svijetu je globalizacija ekonomskih aktivnosti. U suvremenim uvjetima poslovanja, nemoguće je da se poslovni subjekti orijentiraju samo na poslovanje unutar granica neke države te da pri tome posluju izolirano u odnosu na poduzeća u poslovnom okruženju. U globalizacijskim procesima nameću se stroga pravila međunarodnog poslovanja što primorava zemlje da se prilagode tim pravilima ukoliko žele opstati u uobičajenim poslovnim tokovima. Regulaciji međunarodnog poslovanja doprinose i pravila financijskoga izvještavanja uobličena u računovodstvene standarde koja omogućavaju korisnicima iz različitih dijelova svijeta da korištenjem financijskih izvještaja dobiju vjerodostojan uvid u poslovanje nekog poduzeća. U procesima ujednačavanja pravila financijskoga izvještavanja važnu ulogu imaju instrumenti koji se koriste za ostvarivanje tog cilja, a među kojima se posebno ističu Međunarodni standardi financijskoga izvještavanja (MSFI). Najveći broj zemalja u svijetu prihvatio je MSFI-e kao pisane propise financijskoga izvještavanja za jedan dio, ili za sve poslovne subjekte, a velik broj zemalja provodi usklađivanja svojih nacionalnih računovodstvenih standarda s MSFI-ima. Zbog sve većeg broja korisnika kao i povećanja složenosti poslovnih procesa, ovi se standardi često mijenjaju te se prilagođavaju zahtjevima poslovnih subjekata iz različitih gospodarskih podneblja, što je u posljednjih nekoliko desetaka godina rezultiralo, ne samo značajnijim povećanjem obujma standarda, nego i brojnim promjenama koje su imale utjecaja na vrijednost elemenata financijskih izvještaja. Tome u prilog govori i jedna od novijih promjena u računovodstvenih standarda vezana uz obvezu priznavanja imovine i obveza koje proizlaze iz dugoročnih operativnih najmova u bilanci čime se značajno mijenjaju ukupne obveze i imovina onih poduzeća koja u svom portfelju imaju velik udio operativnih najmova. Navedena promjena rezultat je ujednačavanja MSFI-a američkom računovodstvenom praksom (US GAAP-ovima). Materijalni sadržaj financijskih izvještaja ponajprije je zavisan od pravila sastavljanja financijskih izvještaja, odnosno od računovodstvenih standarda. Ako pravila financijskog izvještavanja nisu konzistentna onda to može imati negativne implikacije na kvalitetu računovodstvenih informacija jer njihova primjena u nekim slučajevima neće rezultirati usporedivim i dosljednim računovodstvenim informacijama i to posebice u kratkom 
roku, odnosno u prvom razdoblju nakon stupanja na snagu novih odredbi standarda. U radu su analizirane implikacije koje promjene u standardima mogu imati na informacije prezentirane $u$ financijskim izvještajima u kratkom i dugom roku. Također su identificirane različite vrste promjene standarda koje su potom klasificirane u dvije temeljne skupine, a to su kvalitativne i kvantitativne promjene. Na temelju kronološke analize promjena ukupno 15 standarda (MRS-eva i MSFI-a) koje su zabilježene u razdoblju od 1973. do 2018. godine izvedeni su zaključci istraživanja. Ograničenja ovog rada, zbog njegova obujma, mogu se identificirati u manjem fokusu rada na same okolnosti u kojima su se promjene u standardima odvijale te navedeno može biti smjernica za provedbu daljnjih istraživanja gdje bi se promatrala promjena svakog standarda zasebno u ovisnosti o promjenama nastalim u ekonomskim uvjetima poslovanja.

\section{DONOŠENJE I PROMJENE MEĐUNARODNIH STANDARDA FINANCIJSKOGA IZVJEŠTAVANJA}

\subsection{Utjecaj promjene standarda na vrijednost elemenata financijskih izvještaja}

Osnovni cilj Odbora za međunarodne računovodstvene standarde (eng. International Accounting Standards Board - IASB) je kreirati set visokokvalitetnih računovodstvenih standarda koji bi zadovoljavali informacijske potrebe širokog spektra korisnika, te se zbog toga, kao i zbog neprestanog pritiska brojnih interesno utjecajnih skupina, MSFI-i često mijenjaju. Navedenim promjenama može se utjecati se na financijski rezultat poduzeća koji se iskazuje u računu dobiti i gubitka, a samim time i na uspješnost poslovanja te na prezentirane vrijednosti imovine, obveza i kapitala, odnosno na financijski položaj poduzeća. Još 2010. godine Scanlon i Patch (2010) ističu kako se ovi standardi koriste u preko 100 zemalja u svijetu uključujući sve zemlje Europske unije kao i neke ostale ekonomski razvijene zemlje svijeta kao što su Australija, Japan i Kanada. Danas je broj zemalja koji primjenjuje MSFI-e daleko veći te samo u Americi MSFI-e u nekom obliku koristi preko $80 \%$ zemalja što govori u prilog važnosti analize promjena ovih standarda. Neke od značajnijih promjena koje su se, povijesno gledajući, dogodile u postojećim standardima su: (1) Uvođenje fer vrijednosti što predstavlja jednu od značajnijih promjena s obzirom da vrednovanje imovine po fer vrijednosti ima direktnog utjecaja na bilancu, ali i na račun dobiti i gubitka kroz priznavanje prihoda, odnosno rashoda s osnove promjene fer vrijednosti. Ukoliko dođe do povećanja tržišne vrijednosti neke imovine na datum bilance, uz pretpostavku da se primjenjuje me- 
toda fer vrijednosti (kod određenih stavaka) potrebno je uvećati vrijednost te imovine u bilanci i priznati nerealizirani dobitak što u konačnici uvećava dobit. Prije uvođenja ove metode, koristila se samo metoda troška nabave prema kojoj se promjenom tržišne vrijednosti imovine nije moglo utjecati na financijski rezultat poduzeća. (2) Zabrana korištenja metode LIFO za obračun utroška zaliha što trenutno predstavlja jednu od značajnijih razlika u odnosu na US GAAP-ove (Američka općeprihvaćena računovodstvena načela) koji dozvoljavaju primjenu ove metode. Naime, metoda LIFO je jedna od najčešće korištenih metoda obračuna utroška zaliha u SAD-u (Fosbre, Fosbre and Kraft, 2010). S obzirom da od 2002. godine IASB i američki Odbor za standarde financijskoga računovodstva (eng. Financial Accounting Standards Board - FASB) provode procese usklađivanja ova dva seta standarda, a imajući u vidu da se MRS 2 Zalihe kao jedan od bazičnih standarda nije značajnije mijenjao od 1975. godine kada je izdan, u budućnosti se mogu očekivati daljnje promjene standarda po pitanju zaliha. Korištenjem različitih metoda utroška zaliha direktno se utječe na vrijednost zaliha iskazanih u bilanci, ali i na troškove prodanih zaliha u računu dobiti i gubitka. Odabirom jedne od dozvoljenih metoda utroška zaliha u okviru računovodstvenih politika može se utjecati na financijski rezultat samo kratkoročno, dok se dugoročno nivelira utjecaj računovodstvenih politika. Zbog navedenih činjenica, u radu su istraženi kratkoročni i dugoročni aspekti utjecaja promjena računovodstvenih standarda na kvalitetu financijskoga izvještavanja promatranu kroz temeljna računovodstvena načela usporedivosti i dosljednosti. Dozvoljene metode obračuna utroška zaliha prema MRS-u 2 (Zalihe) nakon ukidanja metode LIFO su FIFO i metoda prosječnih ponderiranih troškova nabave. (3) Osim toga važan je i računovodstveni tretman pojedinih troškova. Poznato je da se troškovi svrstavaju u dvije osnovne kategorije - na dospjele i nedospjele troškove. Dospjeli troškovi iskazuju se kao rashodi u računu dobiti i gubitka, a nedospjeli troškovi iskazuju se kao imovina u bilanci poduzeća. Sukladno tome, neki standardi dozvoljavaju kapitalizaciju troškova, dok drugi te iste troškove smatraju rashodima koji terete prihode obračunskog razdoblja i na taj način umanjuju dobit razdoblja. Promjene u MRS-evima/ MSFI-ima odnosile su se kroz povijest i na računovodstveni tretman troškova pri čemu bi se primjerice u staroj verziji standarda neki trošak smatrao nedospjelim i u tom smislu imovinom, a u revidiranom standardu dospjelim troškom odnosno rashodom čime se promjenom standarda zapravo direktno utječe na financijski rezultat poduzeća kao i na vrijednost imovine iskazane u bilanci. Primjer tome je računovodstveni tretman troškova istraživanja i razvoja prema MRS-u 38 (Nematerijalna imovina). Izvorni standard koji se bavio problematikom iskazivanja troškova istraživanja i razvoja bio je MRS 9 (Računovodstvo za aktivnosti istraživanja i razvoja) prema kojem je u određenim slučajevima bila dozvoljena kapitalizacija troškova istraživanja i razvoja, dok prema aktualnom standardu, kapitalizacija troškova istraživanja nije dozvoljena. 
Prethodno navedene promjene mogu se smatrati kvantitativnima s obzirom da se njihov učinak na informacije prezentirane u financijskim izvještajima može kvantificirati primjenom određenih modela. Osim kvantitativnih promjena u računovodstvenim standardima postoje i kvalitativne promjene kojima se smatraju detaljnija pojašnjenja odredbi standarda, ukidanje određenih nejasnoća ili dodatno pojašnjenje nedorečenih područja u standardima, kao i proširivanje zahtjeva objave informacija u bilješkama uz financijske izvještaje. Nadalje, kvalitativnom promjenom može se smatrati i integriranje više postojećih standarda u jedan novi standard, bez promjena kriterija priznavanja i mjerenja elemenata financijskih izvještaja. Primjer takve promjene je ukidanje MRS-a 4 (Amortizacija) i integriranje njegovih odredbi u standarde koji se bave računovodstvenim tretmanom materijalne i nematerijalne imovine (MRS 16 - Nekretnine, postrojenja i oprema i MRS 38 - Nematerijalna imovina). Od 2001. - 2005. godine, zabilježene su brojne promjene u standardima, a u prilog tome govori činjenica da je u tom razdoblju samo 31 standard ostao na snazi od ukupno izdanih 41 standarda (Paananen and Lin, 2009). Nadalje, u tom je razdoblju izdano osam novih MSFI-a kojih danas ima 17 što znači da je od 2005. godine izdano još 10 novih MSFI-a. Mnogi od tih standarda mijenjani su upravo zbog izrazito važne odluke IASB-a, da dozvoli primjenu metode fer vrijednosti za priznavanje i mjerenje pojedinih elemenata financijskih izvještaja. US GAAP-ovi, s druge strane, ne dozvoljavaju primjenu metode fer vrijednosti za neke oblike nematerijalne i materijalne imovine, već zahtijevaju primjenu metode troška. Dakle i u tom segmentu postoji prostor za usklađivanje ova dva seta standarda, a samim time i za njihove potencijalne izmjene. Uvažavajući promjene u standardima koje su se dogodile u prošlosti, a rezultat su nastojanja IASB-a da kreira što kvalitetnije standarde kao i usklađivanja s Američkim općeprihvaćenim računovodstvenim načelima, u daljnjim je istraživanjima potrebno ukazati i na potencijalne buduće promjene u standardima. Važno je da potencijalni investitori, kao i ostali interni i eksterni korisnici razumiju implikacije koje promjene pojedinih standarda imaju na informacije prezentirane u temeljnim financijskim izvještajima, odnosno da razumiju kakav je utjecaj tih promjena na vrijednost imovine i izvora imovine, a kakav na financijski rezultat. Upravo zbog toga, jedan od osnovnih ciljeva ovog rada bio je identificirati i analizirati učinak promjena najvažnijih MRS-eva/MSFI-a od početka njihova izdavanja do danas na kvalitetu financijskoga izvještavanja.

\section{2. Čimbenici koji utječu na promjene u standardima}

Promjene u računovodstvenim standardima rezultat su brojnih čimbenika. Čimbenici koji se mogu identificirati kao oni koji imaju ključni utjecaj na formalne i suštinske promjene sadržaja standarda navedeni su u nastavku: 
- zahtjevi Europske unije i drugih relevantnih tijela na međunarodnoj razini (IOSCO, Svjetska banka, UN i sl.) koja podupiru uspostavljenje regulatornog okvira koji bi omogućio razumijevanje financijskih izvještaja sastavljenih u različitim dijelovima svijeta, odnosno harmonizaciju financijskoga izvještavanja. Prema Choi i Meek (2008) harmonizacijski procesi znatno su ubrzani tijekom devedesetih godina u vrijeme kada je posebno naglašena globalizacija svjetskih tržišta i rast tržišta kapitala,

- zahtjevi pripadnika pojedinih industrija i grana djelatnosti zbog određenih interesa vezanih uz financijsko izvještavanje; telekomunikacijska industrija, građevinski sektor i sl. (primjer zahtjeva vezanih uz MSFI 15 - Prihodi koji proizlaze iz ugovora s kupcima),

- problemi i nedostatak regulatornog okvira u financijskom izvještavanju banaka i osiguravajućih društava (izdani standardi: MSFI 9 - Financijski instrumenti i MSFI 17 - Ugovori o osiguranju)

- nekonzistentna terminologija u različitim standardima što otežava razumijevanje standarda. Prema Alexander, Britton and Jorissen, (2007) terminološke razlike moguće je pronaći i unutar samog engleskog govornog područja gdje se za iste računovodstvene kategorije primjenjuje različita terminologija što može dovesti do nejasnih prijevoda i iz tog razloga neadekvatne interpretacije standarda,

- zahtjevi za proširenjem informacija koje je potrebno objaviti u bilješka$m a$ uz financijske izvještaje radi bolje informiranosti korisnika financijskih izvještaja,

- usklađivanje MSFI-a s US GAAP-ovima,

- nekonzistentnost u interpretaciji standarda od strane revizora i drugih korisnika standarda zbog nedostataka u MSFI-ima,

- zahtjevi i utjecaj revizora (prema Pelepa, Healy i Peek (2013) revizori su uglavnom protivnici standarda čiju primjenu je zahtjevno kontrolirati, čak i u slučajevima kad standard generira informacije korisne investitorima za donošenje poslovnih odluka),

- različiti interesi vezani uz financijsko izvještavanje (prema Sutton (2000), različite ciljeve financijskoga izvještavanja imaju vlasnici, menadžeri, državna porezna tijela, vjerovnici i ostali regulatori),

- zvorni standardi ponekad nisu pisani potpuno precizno pa se u nekim standardima koristi riječ „treba“ (eng. should), a u drugima „može“ (eng. may) što može dovoditi do zablude treba li se neka odredba primijeniti ili je primjena stvar prosudbe korisnika standarda,

- promjene ekonomskih uvjeta poslovanja i povećanje složenosti poslovnih transakcija, što zahtijeva i donošenje nove računovodstvene regulative, 
- različita primjena istog standarda u istoj industriji što dovodi do neusporedivosti financijskih izvještaja s konkurentima i

- brojni drugi čimbenici.

Može se zaključiti kako se standardi mijenjaju zbog brojnih razloga i da proces kreiranja regulative koja bi bila prilagođena poduzećima u različitim državama i industrijama predstavlja zahtjevan posao. U tom kontekstu, standardi se neprestano mijenjaju pod utjecajem brojnih čimbenika te se radi o procesu koji ce zasigurno potrajati. Prema Botzem (2012) Međunarodni standardi financijskoga izvještavanja su se razvili u skup pravila prvenstveno prilagođenih zahtjevima tržišta kapitala stavljajući velik naglasak na primjenu metode fer vrijednosti. Prema Soderstrom i Sun (2007) IASB ulaže velike napore da poveća kvalitetu Međunarodnih standarda financijskoga izvještavanja što će utjecati na povećanje relevantnosti i pouzdanosti računovodstvenih informacija pripremljenih prema MSFI-ima. Prema Petersen i Plenborg (2012) kvaliteta računovodstvenog sustava definira se kao „financijsko izvještavanje koje pruža informacije koje najbolje podupiru korišteni model za poslovno odlučivanje“. U literaturi koja se bavi problematikom međunarodnoga računovodstva (Leuz i Verrecchia, 2000) navode se dokazi da kvaliteta računovodstvenih informacija ima ekonomske posljedice kao što su trošak kapitala, efikasnost alokacije kapitala te međunarodna mobilnost kapitala. Poznato je da MSFI-e kreira Odbor za međunarodne računovodstvene standarde (eng. IASB - International Accounting Standards Bord) u suradnji s cjelokupnom zainteresiranom javnosti koja je pozvana slati komentare na objavljene nacrte novih standarda ili na potencijalne izmjene postojećih standarda. Takav proces naziva se „obaveznim“ procesom kreiranja standarda (eng. due standard setting process), stoga ni ne čudi kako se obujam standarda sa svakom promjenom povećava budući da IASB kao kreator standarda nastoji zadovoljiti informacijske potrebe velikog broja korisnika standarda koji dolaze iz različitih grana industrije i različitih dijelova svijeta. Naime, danas gotovo da ne postoji zemlja u svijetu koja ne dozvoljava ili zahtijeva primjenu MSFI-a stoga se navedeni standardi mogu nazvati univerzalnim svjetskim jezikom komuniciranja o poslovanju poduzeća. S obzirom na to da je privatnom tijelu dana globalna regulatorna moć po pitanju financijskog izvještavanja, IASB predstavlja primjer ,globalnog privatnog upravljanja“" (Buthe i Mattli, 2005). 


\section{KREIRANJE POLAZNOG MODELA ISTRAŽIVANJA}

\subsection{Uzorak na temelju kojeg je provedeno istraživanje}

U radu su analizirane promjene 15 odabranih MRS-eva/MSFI-a po godinama njihova usvajanja i objavljivanja, a razdoblje za koje su promjene analizirane je od 1973. - 2018. godine. Standardi su odabrani na temelju njihove važnosti u sastavljanju financijskih izvještaja velikih poduzeća. U analizu su obuhvaćeni „bazični“" standardi koji uređuju računovodstveno praćenje najvećeg broja poslovnih promjena svih poduzeća obveznika primjene MSFI-a kao i problematiku sastavljanja temeljnih financijskih izvještaja, te nekoliko specifičnih standarda:

- MRS 1 - Prezentiranje financijskih izvještaja

- MRS 2 - Zalihe

- MRS 7 - Izvještaj o novčanom toku

- MRS 8-Računovodstvene politike, promjene računovodstvenih procjena i pogreške

- MRS 10 - Događaji nakon izvještajnog razdoblja

- MRS 11 - Ugovori o izgradnji (zamijenjen novim standardom 2018. godine - MSFI 15 - Prihodi koji proizlaze iz ugovora s kupcima)

- MRS 16 - Nekretnine, postrojenja i oprema

- MRS 18 - Priznavanje prihoda (zamijenjen novim standardom 2018. godine - MSFI 15 - Prihodi koji proizlaze iz ugovora s kupcima)

- MRS 21 - Učinci promjena tečaja stranih valuta

- MRS 23-Troškovi posudbe

- MRS 27 - Konsolidirani i odvojeni financijski izvještaji (zamijenjen novim standardima MRS 27 - Odvojeni financijski izvještaji) i MSFI 10 Konsolidirani financijski izvještaji)

- MRS 38 - Nematerijalna imovina

- MRS 40 - Ulaganja u nekretnine

- MSFI 5 - Dugotrajna imovina namijenjena prodaji i prestanak poslovanja

- MSFI 12 - Objavljivanje udjela u drugim subjektima.

Na temelju identificiranih ključnih promjena svakog standarda po godinama njihova objavljivanja, analiziran je utjecaj kvantitativnih promjena na kvalitetu financijskoga izvještavanja te su detaljnije pojašnjene kvalitativne promjene i njihov utjecaj na usporedivost, dosljednost i razumljivost informacija prezentiranih u temeljnim financijskim izvještajima. Za identificiranje promjena u standardima 
korišteno je nekoliko izdanja prijevoda MRS-eva/MSFI-a na hrvatski jezik te relevantni dokumenti dostupni na službenim web stranicama Odbora za međunarodne računovodstvene standarde (Međunarodni računovodstveni standardi 1991./1992., prijevod s engleskog jezika, Međunarodni računovodstveni standardi 1996., prijevod s engleskog jezika, 1996, Međunarodni računovodstveni standardi 2000., prijevod s engleskog jezika, 2000., Međunarodni standardi financijskog izvještavanja (MSFI) uključujući Međunarodne računovodstvene standarde i objašnjenja do 31. ožujka 2004., prijevod s engleskog jezika, 2005., Međunarodni standardi financijskog izvještavanja, Narodne Novine 136/2009, Uredba komisije (EZ) br. 1126/2008). U radu su testirane tri hipoteze: H1: „Promjene u računovodstvenim standardima utječu na kvalitetu financijskoga izvještavanja jer onemogućuju primjenu temeljnih računovodstvenih načela dosljednosti $i$ usporedivosti računovodstvenih informacija“. H2: „Kvantitativne promjene u računovodstvenim standardima u kratkom roku narušavaju kriterije usporedivosti i dosljednosti financijskih izvještaja“. H3: „Kvalitativne promjene u računovodstvenim standardima povećavaju kvalitetu financijskoga izvještavanja u dugom roku“.

\subsection{Uloga MRS-a 8-Računovodstvene politike u osiguravanju usporedi- vosti i dosljednosti financijskoga izvještavanja}

Međunarodni standardi financijskoga izvještavanja u svojim odredbama često dozvoljavaju primjenu alternativnih računovodstvenih metoda i postupaka za evidentiranje poslovnih događaja. Kako bi se osigurala usporedivost i dosljednost informacija prezentiranih u financijskim izvještajima, menadžment je dužan odabrati jednu od više dozvoljenih alternativa i dosljedno je primjenjivati u dužem vremenskom periodu. Osnovni cilj MRS-a 8 - Računovodstvene politike, promjene računovodstvenih procjena i pogreške je definiranje kriterija za odabir i promjenu računovodstvenih politika kao i potrebnih objava i računovodstvenog tretmana promjena u računovodstvenim politikama, procjenama te ispravljanju grešaka. Glavna namjena standarda je povećanje primjenjivosti i pouzdanosti financijskih izvještaja, kao i usporedivost podataka u izvještajima društva tijekom vremena i s izvještajima drugih društava (Krajinović, 2012). Uvažavajući važnost navedenog standarda u kontekstu osiguranja usporedivosti i dosljednosti financijskih izvješta$\mathrm{ja}$, analizirane su njegove ključne promjene od datuma izdavanja do danas.

Sukladno provedenoj analizi, uočeno je kako se standard mijenjao dva puta kada mu je ujedno modificiran i sam naziv, i to 1993. te 2003. godine. Jedna od najznačajnijih promjena odnosi se na ukidanje mogućnosti da se prihodi i rashodi iskazuju u izvještaju o dobiti (računu dobiti i gubitka) kao izvanredne stavke. Pre- 
ma modificiranom standardu iz 1993. godine, sve aktivnosti poduzeća smatraju se redovnim, osim potresa i drugih prirodnih katastrofa. U inicijalnoj verziji standarda nije navedeno kako ispraviti temeljne pogreške u financijskim izvještajima, već se odredbe o tome pojavljuju u verziju standarda iz 1993. godine, kada se dozvoljava primjena dva alternativna postupka za ispravljanje pogrešaka i to usklađivanjem početnog stanja zarada ili uključivanjem iznosa ispravka pogreške u dobit ili gubitak razdoblja. Nadalje, standard iz 1993. godine zahtijeva retroaktivno iskazivanje promjene računovodstvenih politika samo ako je to praktično za poduzeće, dok se izmjenom standarda iz 2003.godine zahtijeva retroaktivno iskazivanje takvih promjena, iako su i dalje navedena određena ograničenja retroaktivne primjene za one promjene računovodstvenih politika za koje je neizvedivo odrediti učinke određenog razdoblja ili kumulativne učinke takvih promjena. U ovom izdanju standarda također se ukida dozvoljeni alternativni postupak da se efekti promjena računovodstvenih politika iskazuju u računu dobiti i gubitka tekućeg razdoblja (ostaje samo usklađivanje početnog stanja zadržanih zarada). U svakom novom izdanju standarda proširuje se opseg informacija koje valja objaviti u financijskim izvještajima povezano s promjenama računovodstvenih politika, pogrešaka i ispravljanjem pogrešaka. U 2018. godini, donesena je odluka da se u MRS-u 8 promijeni definicija materijalne značajnosti zbog njezine nekonzistentne primjene u praksi. Ova promjena stupa na snagu 2020. godine. Korisnici MSFI-a često imaju problema s procjenom materijalno značajnih informacija koje treba objaviti u financijskim izvještajima pa se često u praksi događa da se objavljuju irelevantne informacije, dok se bitne informacije stavljaju u drugi plan čime se korisnicima otežava razumijevanje financijskih izvještaja i dobivanje stvarne i cjelovite slike o poslovanju poduzeća.

Temeljna računovodstvena načela usporedivosti i dosljednosti računovodstvenih informacija ponajprije se osiguravaju primjenom ovog standarda koji zahtijeva de se promjene računovodstvenih politika nastale početnom primjenom Standarda ili Tumačenja iskažu u skladu s prijelaznim odredbama, ako ih ima u tom Standardu ili Tumačenju, ili da se iskažu retroaktivno ako Standard ili Tumačenje ne sadrži posebne prijelazne odredbe primjenjive na tu promjenu, međutim, standard, kao što je već spomenuto, navodi ograničenja retroaktivne primjene u slučajevima kad promjenu računovodstvene politike nije izvedivo retroaktivno prikazati (tablica 1). 
Tablica 1.

\section{ANALIZA UČINAKA PROMJENA STANDARDA NA USPOREDIVOST I DOSLJEDNOST RAČUNOVODSTVENIH INFORMACIJA}

\begin{tabular}{|l|l|l|l|}
\hline $\begin{array}{l}\text { VRSTA } \\
\text { PROMJENE } \\
\text { MSFI-a }\end{array}$ & \multicolumn{1}{|c|}{$\begin{array}{c}\text { ZAHTJEVI } \\
\text { STANDARDA }\end{array}$} & $\begin{array}{c}\text { NAČIN POSTUPANJA } \\
\text { S PROMJENOM }\end{array}$ & $\begin{array}{c}\text { UČINAK NA DOSLJEDNOST I } \\
\text { USPOREDIVOST RAČUNOVODSTVENIH } \\
\text { INFORMACIJA }\end{array}$ \\
\hline $\begin{array}{l}\text { Prva } \\
\text { primjena } \\
\text { standarda }\end{array}$ & $\begin{array}{l}\text { Prva primjena standarda } \\
\text { kod poduzeća koji } \\
\text { prethodno nisu bili } \\
\text { obveznici primjene MSFI-a. }\end{array}$ & $\begin{array}{l}\text { Generalno je načelo prve } \\
\text { primjene MSFI-a postupati kao } \\
\text { da se oduvijek primjenjuju pa } \\
\text { MSFI 1 zahtijeva retroaktivnu } \\
\text { primjenu međutim, postoje } \\
\text { brojne iznimke koje } \\
\text { dozvoljavaju prospektivnu } \\
\text { primjenu standarda. }\end{array}$ & $\begin{array}{l}\text { U slučaju nemogućnosti retroaktivne primjene } \\
\text { može biti narušena dosljednost i usporedivost } \\
\text { financijskih izvještaja. Primjer je primjena metode } \\
\text { fer vrijednosti po prvi puta za poduzeće koje je } \\
\text { do promjene standarda koristilo metodu troška za } \\
\text { početno priznavanje i naknadno mjerenje. }\end{array}$ \\
\hline $\begin{array}{l}\text { Promjena uz } \\
\text { postojanje } \\
\text { prijelaznih } \\
\text { odredaba u } \\
\text { standardu }\end{array}$ & $\begin{array}{l}\text { Postupati u skladu s } \\
\text { prijelaznim odredbama }\end{array}$ & $\begin{array}{l}\text { Kod većine promatranih } \\
\text { standarda koje nude prijelazne } \\
\text { odredbe omogućava se } \\
\text { prospektivna primjena } \\
\text { standarda ili se zbog } \\
\text { nemogućnosti retroaktivne } \\
\text { primjene dozvoljava } \\
\text { prospektivna primjena } \\
\text { standarda. }\end{array}$ & $\begin{array}{l}\text { U kratkom roku takvim pristupom može biti } \\
\text { narušen kriterij usporedivosti i dosljednosti } \\
\text { računovodstvenih informacija. Primjer je MRS } \\
\text { 23 - promjenom iz 2007. godine uvodi se obavezna } \\
\text { kapitalizacija troškova posudbe, pri čemu se } \\
\text { odredbe standarda primjenjuju s datumom stupanja } \\
\text { standarda na snagu, ali ne i retroaktivno. }\end{array}$ \\
\hline
\end{tabular}




\begin{tabular}{|c|c|c|c|}
\hline \begin{tabular}{|c|} 
VRSTA \\
PROMJENE \\
MSFI-a \\
\end{tabular} & $\begin{array}{l}\text { ZAHTJEVI } \\
\text { STANDARDA }\end{array}$ & $\begin{array}{l}\text { NAČIN POSTUPANJA } \\
\text { S PROMJENOM }\end{array}$ & $\begin{array}{l}\text { UČINAK NA DOSLJEDNOST I } \\
\text { USPOREDIVOST RAČUNOVODSTVENIH } \\
\text { INFORMACIJA }\end{array}$ \\
\hline $\begin{array}{l}\text { Promjena bez } \\
\text { postojanja } \\
\text { prijelaznih } \\
\text { odredaba } u \\
\text { standardu }\end{array}$ & $\begin{array}{l}\text { Postupati u skladu } \\
\text { s MRS-om } 8 .\end{array}$ & $\begin{array}{l}\text { Retroaktivna primjena osim ako } \\
\text { je neizvedivo. }\end{array}$ & $\begin{array}{l}\text { Mogući su kvantitativni i kvalitativni učinci } \\
\text { u slučaju retroaktivne primjene; u slučaju } \\
\text { nemogućnosti retroaktivne primjene pitanje } \\
\text { dosljednosti i usporedivosti može biti narušeno. } \\
\text { Poduzeća mogu iskoristiti odredbe o neizvedivosti } \\
\text { retroaktivne primjene kako bi opravdala } \\
\text { prospektivno iskazivanje promjena. }\end{array}$ \\
\hline $\begin{array}{l}\text { Dobrovoljna } \\
\text { ranija } \\
\text { primjena } \\
\text { standarda }\end{array}$ & $\begin{array}{l}\text { Prema MRS-u } 8 \text { budući da } \\
\text { ranija primjena standarda } \\
\text { nije dobrovoljna promjena } \\
\text { računovodstvene politike } \\
\text { ne treba se tretirati kao } \\
\text { da je došlo do promjene } \\
\text { računovodstvene politike. }\end{array}$ & $\begin{array}{l}\text { Postupanje uz primjenu } \\
\text { prijelaznih odredbi a u slučaju } \\
\text { da ne postoje prijelazne odredbe } \\
\text { retroaktivna primjena osim ako } \\
\text { je neizvediva. }\end{array}$ & $\begin{array}{l}\text { Mogući su kvantitativni i kvalitativni učinci } \\
\text { u slučaju retroaktivne primjene; u slučaju } \\
\text { nemogućnosti retroaktivne primjene pitanje } \\
\text { dosljednosti i usporedivosti može biti narušeno. } \\
\text { Ovakvim pristupom omogućuje se da različita } \\
\text { poduzeća u istim vremenskim trenucima } \\
\text { primjenjuju različite verzije standarda čime može } \\
\text { biti narušena usporedivost i dosljednost njihovih } \\
\text { financijskih izvještaja. }\end{array}$ \\
\hline $\begin{array}{l}\text { Nepostojanje } \\
\text { standarda ili } \\
\text { tumačenja }\end{array}$ & $\begin{array}{l}\text { NE, MRS } 8 \text { točka } 12 \text { navodi } \\
\text { da menadžment može } \\
\text { primijeniti računovodstvenu } \\
\text { politiku iz najnovijih objava } \\
\text { drugih tijela koja kreiraju } \\
\text { standarde a koriste sličan } \\
\text { konceptualni okvir za } \\
\text { razvijanje računovodstvenih } \\
\text { standarda. }\end{array}$ & \begin{tabular}{|l} 
Postupanje u skladu s \\
odredbama drugih seta \\
standarda a u slučaju da nakon \\
primjene tih odredbi dođe do \\
promjene računovodstvene \\
politike ta se promjena sukladno \\
MRS-u 8 iskazuje i objavljuje \\
kao dobrovoljna promjena \\
računovodstvene politike.
\end{tabular} & $\begin{array}{l}\text { Mogući su kvantitativni i kvalitativni učinci } \\
\text { u slučaju retroaktivne primjene; u slučaju } \\
\text { nemogućnosti retroaktivne primjene pitanje } \\
\text { dosljednosti i usporedivosti može biti narušeno. } \\
\text { U praktičnom se smislu postavlja pitanje, koliko je } \\
\text { poduzeća upoznato s ovom odredbom i koliko njih } \\
\text { je voljno retroaktivne učinke javno objaviti. }\end{array}$ \\
\hline
\end{tabular}


Istraživanje koje je provedeno 2009. godine pokazuje kako malim i srednjim poduzećima najveće problem u primjeni predstavlja HSFI 3 Računovodstvene politike, promjene računovodstvenih procjena i pogreške koji je u velikoj mjeri ekvivalentan odredbama MRS-a 8, te HSFI-a 9 - Financijska imovina. Temeljem rezultata tog istraživanja utvrđeno je kako $10 \%$ malih i srednjih poduzeća uopće ne primjenjuju HSFI što se može povezati sa nepostojanjem internih pravilnika o računovodstvenim politikama odnosno sa neuvažavanjem odredbi ovog posebno značajnog standarda (Smrekar, 2009). Unatoč tome što standard zahtijeva retroaktivnu primjenu, dosadašnja istraživanja pokazuju kako se u praksi ovakav pristup uglavnom ne provodi, čemu u prilog govori i istraživanje provedeno 2009. godine. U uvjetima krize poduzeća produžuju vijek upotrebe sredstava kako bi svjesno utjecala na povećanje dobiti obračunskog razdoblja. Iako ovo ne predstavlja promjenu računovodstvene politike, već računovodstvenih procjena, to može biti indikator njihova postupanja i s promjenama računovodstvenih politika i njihova retroaktivnog iskazivanja. Analizom promjena u standardima uočeno je kako prijelazne odredbe (u slučajevima kada su definirane) uglavnom zahtijevaju prospektivnu primjenu promjena u standardima što ukazuje na to da se promjenama u standardima može negativno utjecati na usporedivost i dosljednost financijskih izvještaja. Ovakve prijelazne odredbe identificirane su između ostalog, u MRS-u 16, MRS-u 38, MRS-u 40, MRS-u 23. Osim toga, donositelj standarda često dozvoljava, a u nemalom broju slučajeva i potiče raniju primjenu standarda, što može rezultirati da poduzeća u istom vremenskom trenutku primjenjuju različite edicije standarda čime može biti narušena usporedivost financijskih izvještaja u kratkom roku. Promjene u standardima potrebno je razmatrati s aspekta materijalne značajnosti koju imaju na vrijednost elemenata financijskih izvještaja. Ukoliko se mijenja određeno pravilo priznavanja ili mjerenja nekog elementa financijskog izvještaja čiji udio nije značajan u strukturi financijskih izvještaja te subjekt takvu promjenu ne iskaže retroaktivno, utjecaj na usporedivost financijskih izvještaja neće biti značajan, drugim riječima, usporedivost financijskih izvještaja neće biti narušena.

Uvažavajući rezultate provedene komparativne analize standarda (tablica 1), može se djelomično potvrditi hipoteza H1: „Promjene u računovodstvenim standardima utječu na kvalitetu financijskoga izvještavanja jer onemogućuju primjenu temeljnih računovodstvenih načela dosljednosti $i$ usporedivosti računovodstvenih informacija.“ 


\section{UTJECAJ KVANTITATIVNIH I KVALITATIVNIH PROMJENA STANDARDA NA USPOREDIVOST I DOSLJENOST FINANCIJSKIH IZVJEŠTAJA}

\subsection{Utjecaj kvantitativnih promjena standarda na usporedivost $i$ dosljed- nost financijskih izvještaja}

Kvantitativnim promjenama smatraju se sve promjene kojima se mijenjaju određene metode priznavanja i mjerenja elementa financijskih izvještaja, čime se utječe na vrijednost pojedinih stavaka prezentiranih u temeljnim financijskim izvještajima, odnosno promjene čiji se učinak na informacije prezentirane u financijskim izvještajima može mjeriti i brojčano iskazati. Promjene kvantitativne prirode mogu se svesti na dva osnovna tipa promjena, a to su ukidanje dozvoljenih alternativnih postupaka te uvođenje novih metoda i postupaka priznavanja te mjerenja elemenata financijskih izvještaja (tablica 2).

Tablica 2.

\section{MODEL MJERENJA KVANTITATIVNIH PROMJENA STANDARDA NA KVALITETU FINANCIJSKOGA IZVJEŠTAVANJA}

\begin{tabular}{|l|l|}
\hline $\begin{array}{l}\text { Kvantitativna } \\
\text { promjena }\end{array}$ & \multicolumn{1}{c|}{ Objašnjenje } \\
\hline $\begin{array}{l}\text { Ukidanje } \\
\text { dozvoljenih } \\
\text { alternativnih } \\
\text { postupaka. }\end{array}$ & $\begin{array}{l}\text { Učinak ukidanja dozvoljenih alternativnih postupaka na informacije } \\
\text { prezentirane u financijskim izvještajima može se kvantificirati. } \\
\text { U kratkom roku, na razini jednog poduzeća, ukidanje dozvoljenog } \\
\text { alternativnog postupka može rezultirati narušavanjem kriterija } \\
\text { dosljednosti i usporedivosti financijskih izvještaja sastavljenih prije i } \\
\text { nakon ukidanja dozvoljenog alternativnog postupka (ako je prije toga } \\
\text { poduzeće za priznavanje i mjerenje elemenata financijskih izvještaja } \\
\text { koristilo ukinuti alternativni postupak). } \\
\text { U dugom roku, na međunarodnoj razini, ukidanje dozvoljenih } \\
\text { alternativnih postupaka rezultira većom usporedivošću financijskih } \\
\text { izvještaja jer poduzeće nemaju ,pravo“ biranja već moraju koristiti ista } \\
\text { pravila priznavanja i mjerenja elemenata financijskih izvještaja. }\end{array}$ \\
\hline $\begin{array}{l}\text { Uvođenje } \\
\text { novih metoda } \\
\text { i postupaka. }\end{array}$ & $\begin{array}{l}\text { Uvođenje novih metoda priznavanja i mjerenja elemenata financijskih } \\
\text { izvještaja u kratkom roku ima jednak utjecaj na usporedivost i } \\
\text { dosljednost financijskih izvještaja na razini jednog poduzeća kao i } \\
\text { ukidanje dozvoljenih alternativnih postupaka. U kratkom roku takva } \\
\text { promjena može rezultirati narušavanjem ovih kriterija, no u dugom } \\
\text { roku se taj utjecaj neutralizira. }\end{array}$ \\
\hline
\end{tabular}


Relevantni zaključci vezani uz utjecaj kvantitativnih promjena na kvalitetu financijskoga izvještavanja doneseni su na temelju provedene detaljne analize promjena u standardima uključenim u uzorak. U tablici 3 navedene su ključne kvantitativne promjene $\mathrm{u}$ odabranim standardima od početka njihova izdavanja. Analizom promjena može se uočiti kako je u 7 standarda ukinut dozvoljeni određeni alternativni postupak čija je primjena bila dozvoljena u prethodnim edicijama standarda, no valja uzeti u obzir činjenicu kako MRS 1 i MRS 7 i MSFI 12 ne propisuju metode priznavanja i mjerenja elemenata financijskih izvještaja zbog čega se kod ovih standarda nije mogla očekivati promjena kvantitativne prirode. Dozvoljeni alternativni postupci nisu reducirani kod MRS-a 16 i MRS-a 38, već je sukladno revidiranim standardima, kao posljedica izdavanja MRS-a 36, dodan zahtjev o testiranju imovine na umanjenje.

Tablica 3.

PRIMJENA MODELA MJERENJA KVANTITATIVNIH PROMJENA STANDARDA NA KVALITETU FINANCIJSKOGA IZVJEŠTAVANJA

\begin{tabular}{|l|l|}
\hline Standard & Ukidanje dozvoljenih alternativnih postupaka. \\
\hline MRS 1 & $\begin{array}{l}\text { NE (standard se ne bavi pravilima priznavanja i mjerenja elemenata } \\
\text { financijskih izvještaja, ne navodi metode priznavanja i mjerenja) }\end{array}$ \\
\hline MRS 2 & $\begin{array}{l}\text { DA } \\
\text { ukinuta primjena metode LIFO, } \\
\text { zabranjena kapitalizacija tečajnih razlika koje nastaju izravno kod nabave } \\
\text { sirovina. }\end{array}$ \\
\hline MRS 7 & NE \\
\hline MRS 8 & $\begin{array}{l}\text { DA } \\
\text { ukinuta alternativa da se usklađivanje nastalo promjenom } \\
\text { računovodstvene politike iskaže u računu dobiti i gubitka tekućeg } \\
\text { razdoblja, } \\
\text { ukinuta alternativa da se prikažu nepromijenjene usporedne informacije } \\
\text { iz financijskog izvještaja prethodnog razdoblja ako dođe do promjene } \\
\text { računovodstvenih politika. }\end{array}$ \\
\hline MRS 10 & $\begin{array}{l}\text { DA } \\
\text { ukinuta alternativa da se izglasane dividende iskazuju u bilanci kao } \\
\text { zaseban dio glavnice. }\end{array}$ \\
\hline MRS 11 & $\begin{array}{l}\text { DA } \\
\bullet \text { ukinuta metoda dovršenog ugovora za priznavanje prihoda ugovora o } \\
\text { izgradnji. } \\
\text { standard 1.1.2018. ukinut i zamijenjen novim standardom - MSFI-em 15 } \\
- \text { Prihodi koji proizlaze iz ugovora s kupcima }\end{array}$ \\
\hline
\end{tabular}




\begin{tabular}{|c|c|}
\hline Standard & Ukidanje dozvoljenih alternativnih postupaka. \\
\hline MRS 16 & $\mathrm{NE}$ \\
\hline MRS 18 & 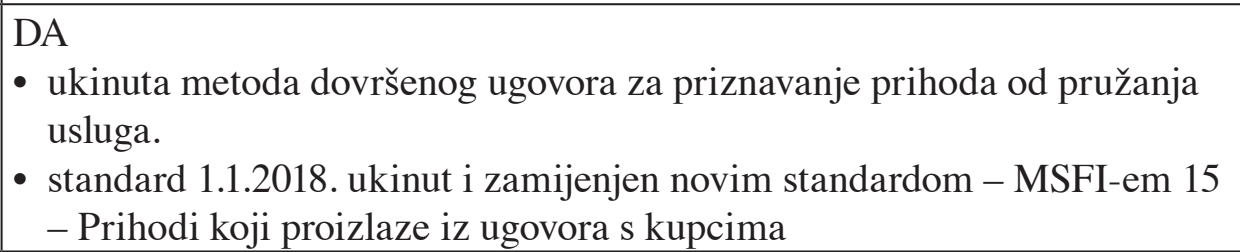 \\
\hline MRS 21 & $\begin{array}{l}\text { DA } \\
\text { - ukinut dozvoljeni alternativni postupak kapitalizacije tečajnih razlika, } \\
\text { - ukinuta glavna metoda iz prethodne verzije standarda prema kojoj se kod } \\
\text { prevođenja financijskih izvještaja inozemnih subjekata monetarne stavke } \\
\text { prevode po zaključnom tečaju, a sve ostale stavke bilance po tečajevima } \\
\text { koji su bili na snazi kada su iznosi stavaka bili određeni, } \\
\text { - ukinuta je alternativa prema kojoj se stavke izvještaja o dobiti kod } \\
\text { prevođenja financijskih izvještaja inozemnih subjekta mogu prevoditi } \\
\text { prema zaključnom tečaju, } \\
\text { - ukinuta je alternativa da se tako utvrđene tečajne razlike iskazuju kao } \\
\text { dio dobiti. }\end{array}$ \\
\hline MRS 23 & $\begin{array}{l}\text { DA } \\
\text { - ukinut dozvoljeni alternativni postupak da se troškovi posudbe za } \\
\text { kvalificiranu imovinu mogu kapitalizirati - prema izmijenjenom } \\
\text { standardu to postaje obavezno. }\end{array}$ \\
\hline MRS 27 & $\begin{array}{l}\text { DA } \\
\text { - ukida mogućnost neprimjenjivanja istih računovodstvenih politika } \\
\text { podružnica ako to nije praktično. }\end{array}$ \\
\hline MRS 38 & $\mathrm{NE}$ \\
\hline MRS 40 & $\mathrm{NE}$ \\
\hline MSFI 5 & $\mathrm{NE}$ \\
\hline MSFI 12 & $\mathrm{NE}$ \\
\hline UKUPNO & - u 7/13 standarda ukinuti su dozvoljeni alternativni postupci \\
\hline Standard & Uvođenje novih metoda i postupaka \\
\hline MRS 16 & Posljedica izdavanja MRS-a 36 - testiranje imovine na umanjenje. \\
\hline MRS 38 & Posljedica izdavanja MRS-a 36 - testiranje imovine na umanjenje. \\
\hline MRS 40 & Primjena metode fer vrijednosti (u odnosu na MRS 25). \\
\hline MSFI 5 & $\begin{array}{l}\text { Mjerenje imovine namijenjene prodaji po vrijednosti nižoj usporedbom } \\
\text { knjigovodstvene vrijednosti i fer vrijednosti umanjene za troškove prodaje. }\end{array}$ \\
\hline $\begin{array}{l}\text { MRS } 11 \\
\text { i } 18\end{array}$ & Zamijenjeni MSFI-em 15 - predstavlja metodu inputa i metodu outputa \\
\hline
\end{tabular}


Jedna od najznačajnijih promjena u smislu uvođenja novih metoda i postupaka priznavanja i mjerenja je uvođenje metode fer vrijednosti za početno priznavanje i naknadno mjerenje ulaganja u nekretnine sukladno MRS-u 40 (prema izvornom MRS-u 25 koji se bavio problematikom ulaganja u nekretnine, metoda fer vrijednosti nije bila dozvoljena). MSFI 5 uvodi nova pravila priznavanja imovine namijenjene prodaji. Pojedini standardi i dalje sadrže dozvoljene alternativne postupke, međutim oni su značajno reducirani u odnosu na izvorne verzije standarda. Dozvoljeni alternativni postupci koji nisu reducirani u postupcima promjene standarda su primjena metode troška i metode revalorizacije. Uvođenje novih metoda i postupaka u standarde uglavnom se odnosi na obavezu testiranja na umanjenje sukladno MRS-u 36 te uvođenje metode fer vrijednosti za početno priznavanje i naknadno mjerenje elemenata financijskih izvještaja. Nadalje, jedna od značajnijih promjena je donošenje novog standarda o prihodima - MSFI-a 15 - Prihodi koji proizlaze iz ugovora s kupcima, koji je nastao suradnjom IASB-a i američkog FASB-a, a koji uvodi metode inputa i outputa za priznavanje prihoda.

Kvantitativne promjene mogu utjecati na usporedivost i dosljednost informacija prezentiranih korisnicima u kratkom roku, jer financijski izvještaji sastavljeni primjenom različitih metoda nisu usporedivi i dosljedni čime se može djelomično potvrditi hipoteza $H 2$ : ,Kvantitativne promjene u računovodstvenim standardima u kratkom roku narušavaju kriterije usporedivosti i dosljednosti financijskih izvještaja." Prijelazne odredbe u standardima uglavnom strogo ne zahtijevaju, već potiču da se objave usporedne informacije (ako se usporedne informacije ne prepravljaju, tu činjenicu treba objaviti), a neke od njih se pozivaju na MRS 8 - Računovodstvene politike, promjene računovodstvenih procjena i pogreške. Istraživanjem promjena u standardima identificirane su dvije osnovne vrste kvantitativnih promjena koje su navedene u tablici 2, a obuhvaćaju ukidanje dozvoljenih alternativnih postupaka i uvođenje novih metoda $i$ postupaka povezanih $\mathrm{s}$ priznavanjem i mjerenjem elemenata financijskih izvještaja Na temelju detaljne analize promjena koje su zabilježene u analiziranim standardima može se donijeti zaključak kako je većina kvantitativnih promjena bila usmjerena prema ukidanju dozvoljenih alternativnih postupaka koji su bili uključeni u izvorne standarde, što posebice karakterizira standarde izdane u razdoblju djelovanja Komiteta za međunarodne računovodstvene standarde (eng. International Accounting Standards Committee - IASC). Spomenute promjene u dugom roku pozitivno utječu na kvalitetu financijskoga izvještavanja promatranu kroz kriterije usporedivosti i dosljednosti računovodstvenih informacija i to posebice na razini više poduzeća, odnosno na međunarodnoj razini, jer poduzeća sukladno odredbama standarda, moraju računovodstveno postupati na isti način. 


\subsection{Utjecaj kvalitativnih promjena standarda na usporedivost $i$ dosljed- nost financijskih izvještaja}

Za utvrđivanje utjecaja kvalitativnih promjena, na kvalitetu financijskoga izvještavanja, odabrano je nekoliko varijabli koje su navedene u tablici 4. Kvalitativnim promjena smatraju se one promjene u standardima koje nemaju numeričkog utjecaja na elemente financijskih izvještaja: imovine, obvezu, kapital, prihode, rashode ili na financijski rezultat. Kvalitativne promjene, iako se ne mogu kvantificirati, ne mogu se smatrati manje važnima u odnosu na kvantitativne promjene.

Analizom promjena u standardima identificirano je nekoliko vrsta kvalitativnih promjena koje su navedene u tablici 4.:

1. dodatni zahtjevi objave informacija u bilješkama uz financijske izvještaje, zbog čega obujam bilježaka, zajedno s obujmom standarda, raste,

2. detaljnije pojašnjenje i preciziranje odredbi u standardima,

3. prebacivanje odredbi iz jednog standarda u drugi postojeći ili novi standard,

4. terminološke promjene,

5. zamjena „blagih“ odredbi koje preporučaju striktno propisanim odredbama koje „zahtijevaju“ (iako se u nekim slučajevima ove promjene mogu smatrati i kvantitativnim promjenama),

6. promjene odredbi jednog standarda utječe na promjene u standardima koji se referiraju na promijenjeni ili modificirani standard.

Tablica 4 .

ANALIZA UTJECAJA KVALITATIVNIH VARIJABLI NA KVALITETU FINANCIJSKOGA IZVJEŠTAVANJA

\begin{tabular}{|l|l|}
\hline $\begin{array}{l}\text { KVALITATIVNA } \\
\text { PROMJENA }\end{array}$ & POJAŠNJENJE UČINAKA PROMJENA NA \\
KVALITETU FINANCIJSKOGA IZVJEŠTAVANJA
\end{tabular}




\begin{tabular}{|c|c|}
\hline $\begin{array}{l}\text { KVALITATIVNA } \\
\text { PROMJENA }\end{array}$ & \begin{tabular}{|l} 
POJAŠNJENJE UČINAKA PROMJENA NA \\
KVALITETU FINANCIJSKOGA IZVJEŠTAVANJA
\end{tabular} \\
\hline $\begin{array}{l}\text { Detaljnije pojašnjenje } i \\
\text { preciziranje odredbi u } \\
\text { standardima. }\end{array}$ & $\begin{array}{l}\text { Detaljnije pojašnjenje odredbi u standardima omogućuje } \\
\text { osobama koje sudjeluju u procesu sastavljanja financijskih } \\
\text { izvještaja lakše razumijevanje standarda i rezultiraju } \\
\text { njihovom lakšom praktičnom primjenom te u konačnici } \\
\text { rezultiraju ukidanjem divergentne primjene standarda od } \\
\text { strane različitih korisnika. Ovaj tip kvalitativne promjene } \\
\text { u standardima rezultira većom usporedivošću financijskih } \\
\text { izvještaja sastavljenih za različite poslovne subjekte. Drugim } \\
\text { riječima, što je odredba nekog standarda bolje pojašnjena, } \\
\text { to je veća vjerojatnost da ce je različiti korisnici razumjeti i } \\
\text { primijeniti na isti način. }\end{array}$ \\
\hline $\begin{array}{l}\text { Prebacivanje odredbi } \\
\text { iz jednog standarda } u \\
\text { drugi postojeći ili novi } \\
\text { standard. }\end{array}$ & $\begin{array}{l}\text { Kvalitativnom promjenom smatra se i tehnička promjena } \\
\text { obuhvata standarda u obliku: } \\
\text { - Spajanja više standarda u jedna novi standard } \\
\text { (primjer MRS-a } 1 \text { u koji su uključene odredbe MRS-a } 5 \\
\text { i MRS-a 13). } \\
\text { - Izuzimanje odredbi koje su bile u djelokrugu postojećeg } \\
\text { standarda i njihovo uključivanje u domenu drugog } \\
\text { postojećeg ili novog standarda (primjer MRS-a } 27 \text { i } \\
\text { MSFI-a 10). } \\
\text { - Ukidanje postojećih standarda i objavljivanje novih } \\
\text { standarda koji na kvalitetniji, sveobuhvatniji način } \\
\text { razrađuju istu problematiku. } \\
\text { Kvalitativne promjene ovakvog tipa mogu imati i pozitivnog, } \\
\text { ali i negativnog utjecaja na snalaženje korisnika u samim } \\
\text { MRS-evima/MSFI-ima. Ovakva promjena u početku } \\
\text { kod osoba koje sastavljaju financijske izvještaje može } \\
\text { biti zbunjujuća te stvoriti dodatne troškove pripremanja } \\
\text { financijskih izvještaja, no u dugom roku pozitivno utječe } \\
\text { na kvalitetu financijskog izvještavanja zbog jasnijeg i } \\
\text { konzistentnijeg pristupanja određenoj računovodstvenoj temi, } \\
\text { uz pretpostavku čistopisa. }\end{array}$ \\
\hline $\begin{array}{l}\text { Terminološke promjene } \\
\text { i promjene naziva } \\
\text { standarda. }\end{array}$ & $\begin{array}{l}\text { Terminološke promjene u početku mogu biti zbunjujuće za } \\
\text { korisnike koji su naviknuti na nazivlje korišteno u prijašnjim } \\
\text { verzijama standarda. U kratkom roku ove promjene mogu } \\
\text { utjecati negativno na razumijevanje standarda, no u dugom } \\
\text { roku niveliraju se negativni utjecaji takvih promjena. }\end{array}$ \\
\hline
\end{tabular}




\begin{tabular}{|l|l|}
\hline $\begin{array}{l}\text { KVALITATIVNA } \\
\text { PROMJENA }\end{array}$ & $\begin{array}{l}\text { POJAŠNJENJE UČINAKA PROMJENA NA } \\
\text { KVALITETU FINANCIJSKOGA IZVJEŠTAVANJA }\end{array}$ \\
\hline $\begin{array}{l}\text { Zamjena ,blagih“ } \\
\text { odredbi koje } \\
\text { „preporučaju“ striktno } \\
\text { propisanim odredbama } \\
\text { koje ,zahtijevaju“. }\end{array}$ & $\begin{array}{l}\text { Pretpostavka je da subjekt neće javno objaviti ono što nije } \\
\text { obavezan prema standardima ili nekoj drugoj regulativi, } \\
\text { zbog čega standardi koji ,preporučaju“ dodatnu objavu nekih } \\
\text { informacija ili dozvoljavaju korisniku da procijeni da li } \\
\text { korist objavljene informacije nadmašuje troškove dobivanja } \\
\text { takve informacije, rezultiraju objavom manjeg obujma } \\
\text { informacija. Također, rizik ovakvih odredbi je njihovo } \\
\text { neujednačeno korištenje na razini više poduzeća. Zamjena } \\
\text { odredbi ,blagog “ karaktera striktno propisanim pravilima } \\
\text { kojih se moraju svi pridržavati rezultira većom kvalitetom } \\
\text { financijskoga izvještavanja. }\end{array}$ \\
\hline $\begin{array}{l}\text { Promjene odredbi } \\
\text { jednog standarda } \\
\text { utječe na promjene } \\
\text { u standardima } \\
\text { koji se referiraju } \\
\text { na promijenjeni ili } \\
\text { modificirani standard. }\end{array}$ & $\begin{array}{l}\text { MRS-evi/MSFI-i su međusobno povezani i referiraju se } \\
\text { jedni na druge što znači da promjena jednog standarda za } \\
\text { sobom povlači promjene u svim drugim standardima koji se } \\
\text { pozivaju na taj promijenjeni standard. Promjene ovakvog tipa } \\
\text { ponekad je kompleksno pratiti zbog čega ovakve promjene } \\
\text { mogu uzrokovati nekonzistentnu primjenu standarda } \\
\text { kombiniranje stare i nove verzije standarda), posebice ako } \\
\text { se ne objavljuju pročišćeni tekstovi standarda već samo } \\
\text { konkretne promjene. }\end{array}$ \\
\hline
\end{tabular}

Kvalitativne promjene koje imaju najvažnijeg utjecaja na kvalitetu financijskoga izvještavanja su;

- dodatni zahtjevi javne objave informacija koje se ne mogu iščitati iz bilježaka, a važne su za donošenje poslovnih odluka te

- detaljnije pojašnjenje i preciziranje odredbi u standardima.

Ove promjene identificirane su u svim analiziranim standardima (tablica 5) i one pozitivno utječu na kvalitetu financijskoga izvještavanja, prije svega na razumljivost temeljnih financijskih izvještaja. Kao posljedica ovakvog tipa promjena, s vremenom raste obujam standarda što u konačnici rezultira opsežnijim i informativnijim bilješkama uz financijske izvještaje (uz pretpostavku da poduzeća dosljedno primjenjuju sve odredbe standarda, uključujući i one vezane uz javnu objavu). U tablicama 5 i 6 nije naveden MSFI 12 kao jedan od novijih standarda budući da nije doživio značajnije promjene. Svrha izdavanja ovog standarda bila je unaprjeđenje financijskoga izvještavanja u pogledu objavljivanja informacija u bilješkama uz financijske izvještaje. 
I. PAVIĆ: Analiza učinaka promjena u međunarodnim standardima financijskoga izvještavanja na usporedivost i... EKONOMSKI PREGLED, 71 (4) 331-357 (2020)

Tablica 5.

PRIMJENA MODELA UTJECAJA KVALITATIVNIH PROMJENA STANDARDA NA KVALITETU FINANCIJSKOGA IZVJEŠTAVANJA (I. DIO)

\begin{tabular}{|c|c|c|c|}
\hline STANDARD & $\begin{array}{c}\text { Dodatni zahtjevi } \\
\text { objave u revidiranim } \\
\text { standardima. }\end{array}$ & $\begin{array}{c}\text { Detaljnije } \\
\text { pojašnjenje i } \\
\text { preciziranje odredbi } \\
\text { u standardima. }\end{array}$ & $\begin{array}{c}\text { Prebacivanje odredbi } \\
\text { iz jednog standarda } \\
\text { u drugi postojeći ili } \\
\text { novi standard. }\end{array}$ \\
\hline MRS 1 & DA & DA & DA \\
\hline MRS 2 & DA & DA & NE \\
\hline MRS 7 & DA & DA & DA \\
\hline MRS 8 & DA & DA & DA \\
\hline MRS 10 & DA & DA & DA \\
\hline MRS 11 & DA & DA & DA \\
\hline MRS 16 & DA & DA & NE \\
\hline MRS 18 & DA & DA & DA \\
\hline MRS 21 & DA & DA & DA \\
\hline MRS 23 & DA & DA & DA \\
\hline MRS 27 & DA & DA & DA \\
\hline MRS 38 & DA & DA & $11-D A / 3-N E$ \\
\hline MRS 40 & DA & $14-$ DA & \\
\hline MSFI 5 & DA & & \\
\hline UKUPNO & $14-D A$ & & DA \\
\hline
\end{tabular}

Promjene koje rezultiraju prebacivanjem odredbi iz jednog standarda u drugi postojeći ili novi identificirane su u 11 standarda, a zapravo se radi o integraciji više standarda u jedan novi kao što je to slučaj kod MRS-a 1 revidiranog 1997. godine koji je nastao integriranjem 3 standarda (postojećeg MRS-a 1, MRS-a 5 i MRS-a 13) ili o izuzimanju odredbi iz jednog standarda zbog potrebe detaljnije razrade problematike koju obrađuje zbog čega dolazi do izdavanja novog standarda (primjer MRS-a 10 iz čijeg su djelokruga izbačeni nepredviđeni događaji i uvršteni u MRS 37). Kod promjene ovakvog tipa mijenja se samo forma standarda, ali ne i suština.

U tablici 6. provedena je analiza ostalih kvalitativnih promjena. Terminološke promjene obuhvaćaju promjene naziva standarda te promjene ostalih termina korištenih u standardima (primjerice naziv izvještaja o promjenama u financijskom položaju promijenjen u izvještaj o novčanom toku - MRS 7, račun dobiti i gubitka u izvještaj o sveobuhvatnoj dobiti - MRS 1, umjesto pojma neuobičajene 
stavke uveden je termin izvanredne stavke i sl.). Promjene ovakvog tipa ne smatraju se suviše značajnima i nemaju tako značajan utjecaj na kvalitetu financijskoga izvještavanja kao dodatni zahtjevi objave i detaljnija razrada standarda, jer su na početku svakog standarda navedene definicije osnovnih pojmova. Promjene koje se pod nekim uvjetima mogu smatrati i kvantitativnim promjenama, a odnose se na zamjenu „,blagih“ odredbi koje preporučaju „strožim“ odredbama koje zahtijevaju, imaju pozitivnog utjecaja na usporedivost i dosljednost prezentiranih računovodstvenih informacija u dugom roku jer onemogućavaju korisniku da sam odluči da li će neku odredbu standarda primijeniti ili neće npr.:

- MRS 13 koji je kasnije spojen s MRS-om 1, dozvoljava da korisnik standarda sam odluči da li će kratkotrajnu imovinu prezentirati odvojeno od dugotrajne imovine i tako omogućiti lakšu ocjenu likvidnosti poduzeća, a promjenom standarda to postaje obavezno.

- MRS 7 u početku nije propisivao niti jednu metodu sastavljanja izvještaja o novčanom toku već je odluka o primjeni određene metode bila na korisniku, kasnije je standardom dozvoljena primjena samo dvije metode; direktne $i$ indirektne.

- MRS 16 je navodio kako procijenjeni ostatak vrijednosti, korisni vijek upotrebe $i$ metodu amortizacije treba preispitati $u$ „određenim vremenskim razmacima", promjenom standarda je ta odredba precizirana $i$ zahtjeva provođenje ovih postupaka najmanje jednom na kraju poslovne godine.

U ostalim standardima nisu postojale „,blage“ odredbe zbog čega nije postojala potreba za njihovom zamjenom ,strožim“ pravilima. Svi standardi su međusobno povezani i u svojim se odredbama referiraju jedni na druge. Ako dođe do promjene nekog standarda, to će najvjerojatnije uzrokovati promjene u drugom standardu na koji postoji referenca, ako ne značajnije, onda zasigurno terminološki. Ovakva vrsta promjena identificirana je u svim standardima. Ovakve promjene mogu u kratkom roku negativno utjecati na razumijevanje i snalaženje u standardima, no u dugom roku negativan utjecaj se neutralizira. Revizijom MRS-a 12007. godine uvodi se pojam sveobuhvatne dobiti i ostale sveobuhvatne dobiti čime su u terminološkom smislu revidirani svi standardi u kojima se promjena tržišne cijene imovine mjeri direktno kroz kapital. 
Tablica 6 .

PRIMJENA MODELA UTJECAJA KVALITATIVNIH PROMJENA STANDARDA NA KVALITETU FINANCIJSKOGA IZVJEŠTAVANJA (II. DIO)

\begin{tabular}{|c|c|c|c|}
\hline STANDARD & $\begin{array}{c}\text { Terminološke } \\
\text { promjene i promjene } \\
\text { naziva standarda. }\end{array}$ & $\begin{array}{c}\text { Zamjena „blagih“6 } \\
\text { odredbi koje } \\
\text {,preporučaju“6 } \\
\text { striktno propisanim } \\
\text { odredbama koje } \\
\text {,zahtijevaju“6. }\end{array}$ & $\begin{array}{c}\text { Promjene odredbi } \\
\text { jednog standarda } \\
\text { utječe na promjene } \\
\text { u standardima } \\
\text { koji se referiraju } \\
\text { na promijenjeni } \\
\text { ili modificirani } \\
\text { standard. } \\
\end{array}$ \\
\hline MRS 1 & DA & DA & DA \\
\hline MRS 2 & DA & $\mathrm{NE}$ & DA \\
\hline MRS 7 & DA & DA & DA \\
\hline MRS 8 & DA & DA & DA \\
\hline MRS 10 & DA & $\mathrm{NE}$ & DA \\
\hline MRS 11 & DA & $\mathrm{NE}$ & DA \\
\hline MRS 16 & DA & DA & DA \\
\hline MRS 18 & $\mathrm{NE}$ & $\mathrm{NE}$ & DA \\
\hline MRS 21 & DA & $\mathrm{NE}$ & DA \\
\hline MRS 23 & DA & $\mathrm{NE}$ & DA \\
\hline MRS 27 & DA & $\mathrm{NE}$ & DA \\
\hline MRS 38 & DA & $\mathrm{NE}$ & DA \\
\hline MRS 40 & $\mathrm{NE}$ & $\mathrm{NE}$ & DA \\
\hline MSFI 5 & DA & $\mathrm{NE}$ & DA \\
\hline UKUPNO & 12-DA, 2-NE & 4-DA/ 10-NE & 14-DA \\
\hline
\end{tabular}

$\mathrm{Na}$ temelju provedene analize kvalitativnih promjena u standardima može se zaključiti kako one pozitivno utječu na kvalitetu financijskoga izvještavanja u dugom roku čime se može potvrditi hipoteza H3: „Kvalitativne promjene u računovodstvenim standardima povećavaju kvalitetu financijskoga izvještavanja u dugom roku." To se prvenstveno očituje u povećanju obujma informacija koje poduzeća moraju, sukladno standardima, objaviti u svojim financijskim izvještajima čime se omogućava bolja informiranost sadašnjih, potencijalnih i budućih investitora, ali i u boljem razumijevanju sadržaja standarda što dovodi do njihove usklađene primjene na razini više poduzeća. 


\section{ZAKLJUČAK}

Budući da je fokus cjelokupnog rada razmatranje promjena u MSFI-ima i njihova utjecaja na kvalitetu financijskoga izvještavanja, u znanstveno istraživačkom procesu identificirani su čimbenici koji utječu takve promjene u Međunarodnim standardima financijskoga izvještavanja, među kojima se posebice ističu; potreba za harmonizacijom financijskog izvještavanja na međunarodnoj razini, preporuke i zahtjevi relevantnih svjetskih organizacija kao što su: Svjetska banka, Europska unija, IOSCO, SEC, FASB i sl., zahtjevi interesno utjecajnih skupina kao što su banke, revizorske tvrtke, osiguravajuća društva i sl., nedovoljna kvaliteta postojećih standarda, reduciranje dozvoljenih alternativnih postupaka u standardima te nedovoljna reguliranost pojedinih računovodstvenih područja u postojećim standardima. Sa svrhom donošenja zaključaka, odabrano je 15 standarda (MRS-eva i MSFI-a) među kojima se nalaze oni koji reguliraju priznavanje i mjerenje materijalno najznačajnijih elementa financijskih izvještaja pa se u skladu s time, njihovim promjenama može najviše utjecati na kvalitetu financijskoga izvještavanja te su analizirane promjene koje su u njima zabilježene od datuma njihova izdavanja do 2018. godine. U skladu s tim, identificirano je koji standardi su se najviše puta mijenjali te su istražene vrste promjena u standardima. Promjene u standardima su klasificirane na kvantitativne promjene - one kojima se mijenjaju pravila priznavanja i mjerenja elemenata financijskih izvještaja te na kvalitativne promjene koje nemaju numeričkog utjecaja na elemente financijskih izvještaja: imovine, obvezu, kapital, prihode, rashode ili na financijski rezultat već podrazumijevaju uvođenje dodatnih zahtjeva objave informacija u financijskim izvještajima, detaljnija pojašnjenja i preciziranje odredbi u standardima te promjene terminološke prirode i sl.

Iako MRS 8 nastoji minimizirati posljedice promjena računovodstvenih standarda kroz retroaktivnu primjenu, ipak rezultati istraživanja upućuju na to kako kvantitativne promjene mogu utjecati na usporedivost i dosljednost informacija prezentiranih korisnicima u kratkom roku jer standard navodi ograničenja retroaktivne primjene u slučajevima kad učinke promjene standarda nije izvedivo retroaktivno prikazati. Kvantitativna promjena u standardu čiji učinak nije iskazan retroaktivno, neće nužno dovesti do narušavanja kriterija usporedivosti financijskih izvještaja ukoliko se ona odnosi na stavku koja nije značajna u strukturi financijskih izvještaja poduzeća. Nadalje, analizom promjena u standardima uočeno je kako prijelazne odredbe (u slučajevima kada su definirane) uglavnom zahtijevaju prospektivnu primjenu promjena u standardima što također ukazuje na to da se promjenama u standardima može negativno utjecati na usporedivost i dosljednost financijskih izvještaja. Osim toga, donositelj standarda često dozvoljava, a u nemalom broju slučajeva i potiče raniju primjenu standarda, što može rezultirati time da poduzeća u istom vremenskom trenutku primjenjuju različite edicije stan- 
darda čime može biti narušena usporedivost financijskih izvještaja na razini više poduzeća. S druge strane, kvalitativne promjene utječu na poboljšanje kvalitete financijskoga izvještavanja u dugom roku što se prvenstveno očituje u povećanju obujma informacija koje poduzeća moraju, sukladno standardima, objaviti u svojim financijskim izvještajima čime se omogućava bolja informiranost sadašnjih, potencijalnih i budućih investitora, ali i u boljem razumijevanju sadržaja standarda što dovodi do njihove usklađene primjene na razini više poduzeća. Navedeno ukazuje na to kako je moguće potvrditi tezu da kvantitativne i kvalitativne promjene nemaju jednakog utjecaja na kvalitetu financijskoga izvještavanja. U radu je znanstveno utemeljenim metodama pokazano kako promjene u računovodstvenim standardima mogu imati utjecaja na kvalitetu financijskoga izvještavanja jer u određenim slučajevima onemogućavaju primjenu temeljnih računovodstvenih načela usporedivosti i dosljednosti računovodstvenih informacija.

\section{POPIS LITERATURE}

1. Alexander, D., Britton, A. i Jorissen, A. (2007) International Financial Reporting and Analysis, 3rd Edition, Thomson, London

2. Botzem, S., (2012) The Politics of Accounting Regulation, Edward Elgar Publishing, Massachusetts, USA

3. Buthe, T. and W. Mattli (2005) Global private governance: Lessons from a National Model Of Setting Standards in Accounting, Law and Contemporary Problems 68 (3/4) $225-262$

4. Choi, F. i Meek, G. (2008) International Accounting, Pearson Prentice Hall, Sixth Edition, New Jersey

5. Deloitte, www.iasplus.org

6. Fosbre, A.,B., Fosbre, P.,B., Kraft, E. M., (2010) A Roadblock to US Adoption of IFRS is LIFO Inventory Valuation, Global Journal of Business Research, Vol. 4, str. $41-49$

7. Krajinović, I., Primjena MRS-a 8 - Računovodstvene politike, promjene u računovodstvenim procjenama i pogreške, Računovodstvo i financije, Hrvatska zajednica računovođa i financijskih djelatnika, Zagreb, 1/2012, str. 94.-101.

8. Leuz, C., Verrecchia, R. (2000) The economic consequences of increased disclosure, Journal of Accounting research, 38, str. 91 -124

9. Međunarodni računovodstveni standardi 1991./1992., prijevod s engleskog jezika, HZRFD, Zagreb, 1992. 
10. Međunarodni računovodstveni standardi 1996., prijevod s engleskog jezika, HZRFD, Zagreb, 1996.

11. Međunarodni računovodstveni standardi 2000., prijevod s engleskog jezika, HZRFD, Zagreb, 2000.

12. Međunarodni standardi financijskog izvještavanja (MSFI) uključujući Međunarodne računovodstvene standarde i objašnjenja do 31. ožujka 2004., (2004) prijevod s engleskog jezika, HZRFD, Zagreb, 2005.

13. Međunarodni standardi financijskog izvještavanja, Narodne Novine 136/2009

14. Paananen, M., Lin, H., (2009) The development of accounting Quality of IAS and IFRS over Time: The case of Germany, Journal of International Accounting Research, Vol 8, str. 31 - 55

15. Palepu, K. G., Healy, P. M., Peek, E. (2013) Business Analysis and Valuation (IFRS edition), Cengage Learning, United Kingdom, str. 10

16. Petersen, C. V., Plenborg, T., (2012.) Financial Statemant Analysis, Prentice Hall, England

17. Scanlon, M.J., Patch, D.P., (2010) a Tough Road Ahead: THE SEC'S Work Plan for Assessing IFRS Adoption by US Public Companies, Accounting, Vol. 24, str. 11-15

18. Sever, I., (2014) Utjecaj promjena računovodstvenih standarda na kvalitetu financijskoga izvještavanja, doktorski rad

19. Smrekar, N. (2009) Utjecaj harmonizacije financijskog izvještavanja na razvoj malih i srednjih poduzeća, magistarski rad, Zagreb, Ekonomski fakultet, voditelj: Žager, Katarina,

20. Soderstrom, S., N., Sun, K.,J., (2007) IFRS Adoption and Accounting Quality: A review, European Accounting Review

21. Sutton T. (2000) Corporate Financial Accounting and Reporting, Prentice Hall, Edhinburg

22. UREDBA KOMISIJE (EZ) br. 1126/2008 od 3. studenoga 2008. o usvajanju određenih međunarodnih računovodstvenih standarda u skladu s Uredbom (EZ) br. 1606/2002 Europskog parlamenta i Vijeća 
I. PAVIĆ: Analiza učinaka promjena u međunarodnim standardima financijskoga izvještavanja na usporedivost i... EKONOMSKI PREGLED, 71 (4) 331-357 (2020)

\title{
ANALYSIS OF CHANGES IN INTERNATIONAL FINANCIAL REPORTING STANDARDS AND ITS EFFECTS ON COMPARABILITY AND CONSISTENCY OF FINANCIAL STATEMENTS
}

\begin{abstract}
Summary
The research goal of this paper was to identify whether continuous changes in the International Financial Reporting Standards affect the comparability and consistency of the financial statements in the short and long term. Paper identifies factors that cause such changes in accounting standards to point out reasons why such changes do appear. In order to achieve scientifically based conclusions, the changes in 15 International Accounting Standards/International Financial Reporting Standards recorded in the period from 1975 to 2018 were analyzed in chronological order. In the research process, the available literature with the content of standards valid at a certain point in time was analyzed. Different standards' editions have been analyzed using appropriate scientific methods; analysis, synthesis, comparative method, induction and deduction methods, and other relevant scientific methods. Research showed that changes in accounting standards may have an impact on the quality of financial reporting in certain cases because changes distort the application of fundamental accounting principles - comparability and consistency. The scientific contribution of this paper is the identification and systematization of key changes in IFRSs and conclusions on its impact on the quality of financial reporting of all companies applying IFRSs.
\end{abstract}

Key words: IFRS, changes, comparability, consistency, financial statements, accounting standards 